\title{
Diel variation in egg-laying by the freshwater fish louse Argulus foliaceus (Crustacea: Branchiura)
}

\author{
A. J. Harrison ${ }^{1, *}$, N. F. S. Gault ${ }^{2}$, J. T. A. Dick ${ }^{3}$ \\ ${ }^{1}$ Queen's University Belfast, Fisheries and Aquatic Ecosystems Branch, Department of Agricultural and Environmental \\ Science, Newforge Lane, Belfast, BT9 5PX, UK \\ ${ }^{2}$ Agri-Food and Biosciences Institute, Food Science Division, Newforge Lane, Belfast, BT9 5PX, UK \\ ${ }^{3}$ Queen's University Belfast, School of Biological Sciences, 97 Lisburn Road, Belfast, BT9 7BL, UK
}

\begin{abstract}
Removal of deposited eggs could be a useful control strategy for the damaging fish ectoparasite Argulus foliaceus, but focused control requires knowledge of egg-laying patterns. Here, we investigated diel changes in the egg-laying behaviour of a natural population of A. foliaceus. Data were collected from 17-28 May 2004. Days were divided into 3 time periods: 06:00-14:00, 14:0022:00 and 22:00-06:00 h. Significantly more egg clutches were laid from 06:00-14:00 h than during the other 2 time periods, which were not significantly different from each other. Significantly more egg clutches per hour were laid during hours of daylight as compared to hours of darkness. Significantly more egg clutches were laid in the top $1 \mathrm{~m}$ of the water column than at the bottom, and this was consistent throughout all 3 time periods. It is suggested that the increase in egg-laying activity during daylight hours may be due to a higher motivation to search for hosts during the night and an increased ability to locate silhouetted egg-laying sites during the day. These data can provide information useful for egg removal and control strategies.
\end{abstract}

KEY WORDS: Argulus foliaceus $\cdot$ Freshwater fish louse $\cdot$ Egg-laying $\cdot$ Diel variation $\cdot$ Depth $\cdot$ Parasite Rainbow trout

Resale or republication not permitted without written consent of the publisher

\section{INTRODUCTION}

The freshwater fish louse Argulus foliaceus is a damaging branchiuran fish ectoparasite common throughout Europe and is found on many species of freshwater fish in Britain and Ireland (Bower-Shore 1940, Holland \& Kennedy 1997, Bark 2000). It feeds by piercing the skin of the host, with heavy infestations leading to serious skin damage, stress and death (Hoffman 1977, Kabata 1985). Recently, serious epizootics and subsequent loss of fish stocks have led to closures of rainbow trout Oncorhynchus mykiss fisheries in Scotland (Northcott et al. 1997) and Northern Ireland (Gault et al. 2002).

To date, there has been fairly extensive work conducted on the egg-laying behaviour of Argulus foliaceus. However, this work has mainly concentrated on laboratory populations of lice under artificial conditions (e.g. Pasternak et al. 2000). The mechanics of egg-laying are well understood and have been observed in detail in the laboratory (Bower-Shore 1940, Bauer 1959, Pasternak et al. 2000). Copulation in A. foliaceus usually occurs on the host fish, after which the female leaves the host in order to lay her eggs on most readily available hard substrata (Hoffman 1977). Pasternak et al. (2000) observed that female argulids lay 2 to 4 egg clutches, then return to a host, before detaching again to lay another batch within 2 to $4 \mathrm{~d}$.

Unlike the mechanics of egg-laying, spatial and temporal patterns in egg-laying activity of Argulus foliaceus in natural conditions are less well understood. Seasonality and vertical distribution in egg-laying activity of $A$. foliaceus in natural conditions have been demonstrated by Harrison et al. (2006). In contrast, no work has been conducted on the small-scale temporal distribution of egg-laying by A. foliaceus, in particular with regards to diel variation in egg-laying activity. After a thorough literature search, only one reference 
could be found on the topic (Kimura 1970), and this was in relation to another species of argulid, Argulus japonicus, a common parasite of cultured carp Cyprinus carpio. This species has recently been introduced into Britain with goldfish as a result of the ornamental fish trade from Southeast Asia (Rushton-Mellor 1992). Kimura (1970) notes that, in experimental conditions, egg deposition of A. japonicus was observed exclusively under dark conditions. He concludes that this species of freshwater fish louse is therefore considered to lay its eggs mostly during the night in fish farms, although this was not tested directly.

Control strategies for Argulus spp. based on removal of deposited eggs have yielded some success (Bauer 1959, Shimura 1983, Gault et al. 2002). Floating wooden boards have been used in Eastern Europe as a substrate for A. foliaceus egg-laying (Bauer 1959), whilst transparent acrylic plates have been adopted in Japan to facilitate removal of A. coregoni egg clutches from fish-rearing ponds (Shimura 1983). Efficient control, however, relies on our understanding of both seasonal and diel egg-laying patterns of these species (Harrison et al. 2006).

The aim of this study was to investigate diel patterns in egg-laying activity of Argulus foliaceus in a natural population. Understanding the processes involved at this critical stage in the life cycle of $A$. foliaceus is essential for the development of appropriate control methods based on interrupting the life cycle of this commercially important parasite species.

\section{MATERIALS AND METHODS}

Study site. Lower Ballysallagh reservoir is a 12.9 ha rainbow trout Oncorhynchus mykiss fishery located near Bangor, County Down, Northern Ireland $\left(54^{\circ} 37^{\prime} \mathrm{N}, 5^{\circ} 45^{\prime} \mathrm{W}\right)$. The fishery has a recent history of a high prevalence of Argulus foliaceus, with epizootics resulting in massive fish kills in 1995, 1999 and 2002 (N. F. S. Gault pers. obs.). The lake is used as a municipal water supply by the Department for the Environment. It is moderately eutrophic with a maximum depth of $7.2 \mathrm{~m}$ and has a resident population of threespined sticklebacks Gasterosteus aculeatus, which also acts as a host for A. foliaceus.

Sampling. Eggs of Argulus foliaceus were collected on $30 \times 30 \mathrm{~cm}$ corrugated polypropylene boards (see Harrison et al. 2006). Each board string consisted of 5 boards suspended vertically from an anchored rope. Ten board strings were positioned 10 to $20 \mathrm{~m}$ from the bank along 2 sides of the reservoir, the boards at depths of $0,1,2$ and $3 \mathrm{~m}$ (rope), and $5.5 \mathrm{~m}$ (anchor). The boards were first checked on 17 May 2004 at 06:00 $\mathrm{h}$ and at $8 \mathrm{~h}$ intervals thereafter for $9 \mathrm{~d}$. Through- out the course of the study, sunrise varied from 04:59 to 05:14 $\mathrm{h}$ and sunset from 21:27 to 21:44 h. To confirm that all eggs collected represented $A$. foliaceus without contamination from other species, we collected and hatched a representative sample of egg clutches over a $3 \mathrm{yr}$ period and identified the resulting individuals all as conspecific with $A$. foliaceus.

Analyses. Two separate analyses were conducted (Statview version 5.0, SAS Institute). Firstly, the total number of egg clutches over the $9 \mathrm{~d}$ was collapsed into 3 time periods (06:00-14:00, 14:00-22:00 and 22:0006:00 h) and the data analysed using a 2-factor ANOVA with respect to depth and time period (repeated measures). Scheffe's post-hoc test was used for pairwise comparisons of means. Secondly, in order to investigate differences in egg-laying between day (hours of light) and night (hours of darkness), we calculated the number of egg clutches per hour for 'light' (06:00-22:00 h) and 'dark' (22:00-06:00 h) and compared these means using a paired $t$-test. An alpha level of $p<0.05$ was used for testing statistical significance in all analyses.

\section{RESULTS}

There was a significant difference in the number of egg clutches laid among the 3 time periods $\left(F_{2,72}=4.86\right.$, $\mathrm{p}<0.05$; Fig. 1) and among depths $\left(F_{4,72}=9.38, \mathrm{p}<\right.$ 0.0001; Fig. 1). There was no significant 'time $\times$ depth' interaction effect $\left(F_{8,72}=1.01\right.$, not significant), indicating that this depth pattern was consistent throughout the 3 time periods (Fig. 1). Scheffe's post-hoc test showed that significantly more egg clutches were laid during the time period 06:00-14:00 $\mathrm{h}$ than during 22:00-06:00 $\mathrm{h}(\mathrm{p}<0.05)$. The number of eggs laid in the time period 14:00-22:00 h was not significantly differ-

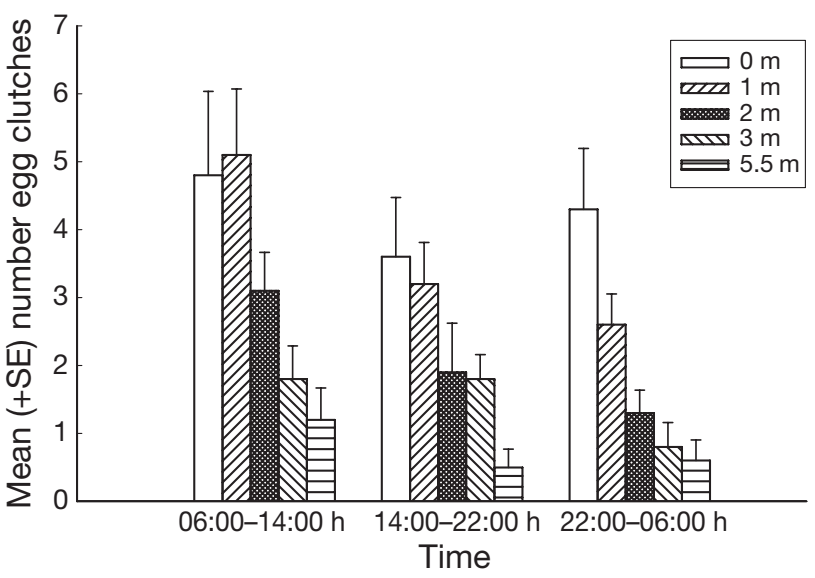

Fig 1. Argulus foliaceus. Mean (+SE) number of egg clutches laid during each time period, at 5 different depths over the $9 \mathrm{~d}$ monitoring period 
ent from either 06:00-14:00 or 22:00-06:00 h. Scheffe's post-hoc test also showed that significantly more egg clutches were laid at the surface or $1 \mathrm{~m}$ than at $3 \mathrm{~m}$ or on the bottom ( $p$-values ranging from $<0.05$ to $<0.0004)$. When data were grouped by 'daytime' versus 'night-time', mean number of egg clutches laid per hour was significantly greater during the day $(1.689 \pm$ $0.175 \mathrm{SE})$ than during the night $(1.202 \pm 0.119 \mathrm{SE})\left(t_{9}=\right.$ $2.24, \mathrm{p}<0.05)$.

\section{DISCUSSION}

Clearly, there are diel patterns in egg-laying activity of Argulus foliaceus, with significantly more egg clutches being laid during the time period 06:0014:00 $\mathrm{h}$ than during the time period 22:00-06:00 $\mathrm{h}$. Furthermore, when the 'daytime' periods were combined, the mean number of egg clutches laid per hour was significantly less during hours of darkness than during hours of daylight.

These findings are in contrast to those of Kimura (1970), who observed egg deposition by Argulus japonicus to be exclusively restricted to dark conditions. He concluded that water lice, therefore, mainly lay their eggs during the night at fish farms. His work, however, was conducted in an experimental setting where host availability is perhaps likely to be artificially high and, hence, natural host finding and egglaying behaviours may not be exhibited.

Previous authors have demonstrated differences in the behaviour of Argulus foliaceus between periods of light and dark with respect to their host finding strategies, the highest infection rate being in times of darkness (Mikheev et al. 1998). Also, it has been shown that A. foliaceus adopts different strategies for host finding between dark and light conditions. In darkness, the mean swimming speed and area explored was shown to be 3 to 4 times higher than in light; that is, a cruising search strategy is employed in the dark, whereas an ambush (hover and wait) strategy is employed in the light (Mikheev et al. 2000).

Differences in host swimming activity between periods of light and dark are likely to play a major role in the diel activity and subsequent infection rates of Argulus foliaceus. In experimental conditions, juvenile perch were shown to adopt a significantly slower swimming speed, and also stopped more frequently in periods of dark compared to periods of light (Mikheev et al. 2000). Spatial distribution of fish also varies on a diel scale, with most fish species rising and spreading throughout the water column at night, as seen during hydroacoustic surveys, where fish numbers recorded at night can be significantly greater than those recorded during the day (A. J. Harrison pers. obs.).
These differences in host behaviour, and the subsequent observed changes in host finding strategies, would presumably make it much easier for actively seeking $A$. foliaceus to locate and attach to a host in the dark than in the light.

Such behavioural differences on a diel scale, both in host finding strategies of Argulus foliaceus and in the spatio-temporal distribution of potential host fish, may be partly responsible for the diel patterns in egg-laying activity exhibited in this study. For example, during the hours of darkness (the 'optimum' time during which to find a host) more emphasis may be placed on host finding than on egg-laying. Egg-laying could then be concentrated on daylight hours when host finding becomes less effective.

The ability of Argulus foliaceus to find the egg-laying boards used in this study (and presumably most other available hard substrata) may also be affected by the availability of light. This has been demonstrated in other crustacean species. Caligid copepods, for example, have been shown to be attracted to the shadow of floating objects such as logs (Kabata 1981). It would be reasonable to assume that egg-laying boards, particularly those at the surface, would be more distinguishable during the day than at night. The $30 \times 30 \mathrm{~cm}$ black boards would be seen as a dark silhouette, and would cast a shadow over anything swimming underneath. Significantly more egg clutches were laid in the top metre of the water column than at the bottom and thus the importance of this dark silhouette effect could have played an important role in the observed increase in egg-laying during the time period 06:00-14:00 $\mathrm{h}$.

In this investigation, diel activity patterns in egg-laying behaviour of Argulus foliaceus have been demonstrated, providing useful information that could be used in the ecological control of this species. For example, the use of egg-laying boards to collect and remove egg clutches could be temporally targeted at the most productive egg-laying period, which was between 06:00 and 14:00 h. Gault et al. (2002) used egg-laying boards which were submerged for 2 wk periods to collect egg clutches in a stillwater fishery. Although leaving boards submerged for $8 \mathrm{~h}$ out of every $24 \mathrm{~h}$ period would not provide a control which is as effective as leaving them submerged for $2 \mathrm{wk}$ before removal, it may not be practical in a fish farm situation to have boards permanently in raceways. In this case, it is beneficial to know at what time of the day the most effective control would be achieved.

Based on the results of this investigation, it is suggested that the diel variation in egg-laying activity displayed by Argulus foliaceus is likely to be the result of a combination of the factors discussed. An increase in host searching motivation (and hence less emphasis on egg-laying) during hours of darkness, and a potential 
increase in the ability to locate silhouetted egg-laying sites during hours of daylight, are thought to be important factors governing diel egg-laying patterns in this parasite species.

Acknowledgements. We thank Bangor Angling Club for their cooperation in this study and for the use of their facilities. We also thank all those who assisted with data collection, who are too many to name. This work was funded through a $\mathrm{PhD}$ studentship to A.J.H. from the Department for Employment and Learning Northern Ireland.

\section{LITERATURE CITED}

Bark S (2000) Argulus. Fish Farmer 23:40

Bauer ON (1959) The ecology of parasites of freshwater fish. In: Parasites of freshwater fish and the biological basis of their control. Bull St Sci Res Inst Lake River Fish 49:3-207. (Translated from Russian: Israel Program for Scientific Translations, Jerusalem, 1962)

Bower-Shore C (1940) An investigation of the common fish louse, Argulus foliaceus (Linn.). Parasitology 32:361-371

Gault NFS, Kilpatrick DJ, Stewart MT (2002) Biological control of the fish louse in a rainbow trout fishery. J Fish Biol 60:226-27

Harrison AJ, Gault NFS, Dick JTA (2006) Seasonal and vertical patterns of egg-laying by the freshwater fish louse Argulus foliaceus (Crustacea: Branchiura). Dis Aquat Org 68:167-173

Hoffman GL (1977) Argulus, a branchiuran parasite of freshwater fishes. Fish Disease Leaflet 49. United States Department of the Interior, Fish and Wildlife Service,

Editorial responsibility: Robin Overstreet, Ocean Springs, USA
Washington, DC

Holland CV, Kennedy CR (1997) A checklist of parasitic helminth and crustacean species recorded in freshwater fish from Ireland. Proc R Ir Acad Sect B Biol Environ 97:225-243

Kabata Z (1981) Copepoda (Crustacea) parasitic on fishes: problems and perspectives. Adv Parasitol 19:1-71

Kabata Z (1985) Parasites and diseases of fish cultured in the tropics. Taylor \& Francis, London

Kimura S (1970) Notes on the reproduction of water lice (Argulus japonicus Thiele). Bull Freshw Fish Res Lab Tokyo 20:109-126

Mikheev VN, Valtonen ET, Rintamaki-Kinnunen P (1998) Host searching in Argulus foliaceus L. (Crustacea: Branchiura): the role of vision and selectivity. Parasitology 116:425-430

Mikheev VN, Mikheev AV, Pasternak AF, Valtonen ET (2000) Light-mediated host searching strategies in a fish ectoparasite, Argulus foliaceus L. (Crustacea: Branchiura). Parasitology 120:409-416

Northcott SJ, Lyndon AR, Campbell AD (1997) An outbreak of freshwater fish lice, Argulus foliaceus L., seriously affecting a Scottish stillwater fishery. Fish Manag Ecol 4:73-75

Pasternak AF, Mikheev VN, Valtonen ET (2000) Life history characteristics of Argulus foliaceus L. (Crustacea: Branchiura) populations in Central Finland. Ann Zool Fenn 37:25-35

Rushton-Mellor SK (1992) Discovery of the fish louse, Argulus japonicus Thiele (Crustacea:Branchiura), in Britain. Aquac Fish Manag 23:269-271

Shimura S (1983) Seasonal occurrence, sex ratio and site preference of Argulus coregoni Thorell (Crustacea: Branchiura) parasitic on cultured freshwater salmonids in Japan. Parasitology 86:537-522

Submitted: January 8, 2007; Accepted: August 14, 2007 Proofs received from author(s): October 29, 2007 